ROCZNIKI HUMANISTYCZNE

Volume 67, issue $2-2019$

SELECTED PAPERS IN ENGLISH

DOI: http://dx.doi.org/10.18290/rh.2019.68.2-6en

ARKADIUSZ MICHAE STASIAK

\title{
JUSTICE AS THE AIM OF THE MONARCH'S AUTHORITY: THE EVOLUTION OF THE IDEA FROM PLATO TO THE CLOSE OF THE ENLIGHTENMENT
}

In the traditionalist and republican ideologists' appraisal, conquests and the suppression of subjects' freedom were the monarch's superior aims. The confrontational character of these ideas was obvious: a republic was a peaceful formation, it was only interested in maintaining its state of possession. Moreover, it was the cradle of freedom. Owing to this freedom a republic was able to function. Luckily for the discussion below, even such seemingly unrealistic aims of the monarch's authority still remain its aims. It is worth returning to these aims to construct great monarchist theories based on them. It is so because their unattainability does not influence the demands to carry them out.

What is important is that all hierarchies - as Richard M. Weaver noted and especially a monarchist hierarchy, requires that the aims should be jointly defined by the interested sides. ${ }^{1}$ Hence, the aims of the authorities may not be the result of individual constructs. They are to a large degree the effect of the subjects' expectations and a reply to these expectations given by the theoreticians of the authority.

Even this very initial assumption of the present article is a determining one. This is because I assume that politics is a means of realizing a social aim whose character is extra-political. I think that such a perspective may be adopted for studying the idea of authority. Furthermore, by appraising the

Dr. hab. Arkadiusz Michą StasiaK - John Paul II Catholic University of Lublin, Institute of History, Department of History of the $16^{\text {th }}-18 \mathrm{t}^{\mathrm{h}}$ centuries; address for correspondence: Al. Racławickie 14, 20-950 Lublin; e-mail: arcus@kul.pl.

The Polish version of the article was published in Roczniki Humanistyczne 58 (2010), issue 2.

${ }^{1}$ Richard M. WEAVER, Idee maja konsekwencje [Ideas Have Consequences], trans. Barbara Bubula (Kraków: Profesjonalna Szkoła Biznesu, 1996), 42. 
adopted aim that power serves (the aim that is defined for the authority by the theoreticians) one may define the system of values "professed" by an ideal ruler. In this case, theoretical deliberations do not include the aim frequently realized in history, that is, power for power's sake. It seems that such a question - of gaining power for power itself - has not been asked in Polish modern theory. It has been an issue primarily concerned with the practical sphere. Such an attitude (of making the aim of the ruling power gained just be in power) raises a question I have not found in the Polish discourse on authority - is it good to have power? This question has often stirred up discussions. By saying that "man is a political animal", Aristotle proved that by engaging in political activity we realize our fundamental abilities. He thought that having power is a source of enrichment of life that cannot be compared to anything else. Epicurus perceived this question in a different way. He sought peace in a life that gives subtle pleasures, and in being free from suffering ("to live in obscurity"). And politics is precisely the opposite to a quiet life, since it means ceaseless annoyances and a dependence on others. New relativist motifs were introduced to this discussion by Machiavelli. For him, power was justified by glory and by the excitement that is aroused by political virtuosity. Searching for the idea of power I could even assume that a love for power will never be stronger than the desire for some aim that may be realized thanks to exercising power. And, in addition, that wielding power will never afford satisfaction, unless the ruler's superior aim is achieved. I also assume that searching for the aim of power is an activity that is profitable, not only for the ruler but also for others.

I am not going to examine in the present considerations the systemiclegal duties of the king. That is a completely different dimension of power, having a systemic, and not ideological, character. In Polish theory these aims of the ruler have often been reduced to simply obeying the law and the freedom of the nation of noblemen.

Is the ruler's ultimate aim, then, to make it possible for individuals to live according to their choice? From the very beginning it should be pointed out that an affirmative answer to this question will not mean that the modern theory of power should be inscribed in the current of the liberal tradition in the Lockean meaning. Answering yes, that the aim of those wielding power was to ensure the rule of justice, I will not discover the dominating current, but just the diversity of theories about power.

The source on which my article is based consists of political treatises and works with a character close to this form. The starting point for the delibera- 
tions is Plato's Statesman. In this journey through the meanderings of political theory I have referred to numerous treatises, but I have primarily concentrated on European modern thought in order to present in the final part of the article the ideas of justice as the aim of the monarch's authority in the First Republic of Poland. It is for this reason that in the final part of the discussion I so frequently quote such authors as Józef Wybicki, Józef de PugetPuszet and Stanisław Staszic. The fundamental work on the theory of justice in the meaning being searched for here is Otfried Höffe's book Politische Gerechtigkeit: Grundlegung einer kritischen Philosophie von Recht und Staat. $^{2}$ Furthermore, the famous book by John Rawls A Theory of Justice ${ }^{3}$ may not be omitted; this book is especially significant for construing a theoretical formula. In Poland the issue of justice was most fully presented by Wojciech Sadurski (Teoria sprawiedliwości. Podstawowe zagadnienia [The Theory of Justice. Fundamental Issues]). ${ }^{4}$ Philosophical reflection also supplies extensive literature on justice. Among the most recent works Antoni Siemianowski's "Sprawiedliwość [Justice]," Ryszard Kleszcz's "Co to znaczy 'sprawiedliwość'?," Andrzej Pawelec's "Ontologia sprawiedliwości [The Ontology of Justice]" 7 are especially interesting. However, there are no analyses trying to capture the essence of the issue in the Republic of Poland in the second half of the $18^{\text {th }}$ century. An analysis of the theory of justice in a natural way results in a moral appraisal of the reign. The ideas of justice of the authorities in Poland were not determined by the experience of the $16^{\text {th }}$ and $17^{\text {th }}$ century religious wars (and to a lesser degree, of the political disputes), unlike in modern West-European political reflection. It was from such experiences that the political theories developed by such great authors as Jean Bodin, Thomas Hobbes and Hugo Grotius stemmed. As a result of this, this moral appraisal of a king's personal justice could be the result primarily of the criticism of political relations. In this process, a special role was played by the experience of oppression; it could result from personal authority, it was a kind of tension within the class of noblemen, or finally the

\footnotetext{
${ }^{2}$ Otfried HöFfe, Sprawiedliwość polityczna. Podstawy krytycznej filozofii prawa i państwa [Political Justice. The Foundations of Critical Philosophy of the Law and the State; German orig. Politische Gerechtigkeit: Grundlegung einer kritischen Philosophie von Recht und Staat], trans. Jarosław Merecki, Kraków: Znak, 1999.

${ }^{3}$ John Rawls, Teoria sprawiedliwości [A Theory of Justice], trans. Maciej Panufnik, Jarosław Pasek, and Adam Romaniuk (Warszawa: Wydawnictwo Naukowe PWN, 1994).

${ }^{4}$ Wojciech SAdurski, Teoria sprawiedliwości. Podstawowe zagadnienia [The Theory of Justice. Fundamental Issues] (Warszawa: Wydawnictwo Sejmowe), 1988.

${ }^{5}$ Antoni SiemianowsKi, "Sprawiedliwość (Justice)," Logos i Ethos 1993, No. 2: 7-31.

${ }^{6}$ Ryszard Kleszcz, “Co to znaczy 'sprawiedliwość'? [What Does 'Justice' Mean?”, Filozofia Nauki 1999, No. 1/2: 31-41.

${ }^{7}$ Andrzej PAwELEC, "Ontologia sprawiedliwości (The Ontology of Justice)," Civitas 2000, No. 4: 133-143.
} 
breaking of the "human rights" of the lowest classes of the population. All these kinds of experience of oppression led to the idea of freedom from authorities.

Justice as the necessary condition of human life, and not a kind of moral luxury, conditions many aims of the authorities. In harmony with European political philosophy, this connection between justice and other ideas belonging to the sphere of the theory of authority is especially revealed in its striving for peace (opus iustitiae pax - peace is the fruit of justice). ${ }^{8}$ Moreover, the theory of enforcing the law (a just law) is in a fundamental way connected with the idea of justice. ${ }^{9}$ There are also fundamental connections between justice and the theory of social contract. As John Rawls argues, the rules of social justice established for a community are the subject of a primeval contract. ${ }^{10}$ Political equality has a colossal significance for the idea of the justice of the authority, since the distribution of wealth and access to state offices (remaining within the monarch's remit) should be equal. In the case of an unequal distribution of wealth, freedom and respect, the injustice will simply be inequality. Moreover, the Enlightenment anthropology and the antitraditionalist climate of the epoch enhanced the exceptionally close relationships and connections between such ideas as equality, freedom and justice.

The very term "justice" is a predicate of objective appraisal. By calling the authority "just" we express our acceptance of it, but we also pronounce its compliance with the law (validity). By defining it as "unjust" we express our disapproval of an invalid and false authority.

And finally, analyzing the idea of justice of a personal authority, one should clearly distinguish personal praxis from institutional praxis. The former implies the principles and attitudes of a natural person and, as such,

\footnotetext{
${ }^{8}$ The model of this mutual, determined relationship comes from the Bible, Psalm 84 (85) 11, Isa 32:17. See also: Wolfgang PleISTER, "Mythos des Rechts," in Recht und Gerechtigkeit im Spiegel der europäischen Kunst, ed. Wolfgang Pleister, and Wolfgang Schild (Köln: DuMont, 1988), 29-32. However, in the Bible the term "justice" occurs in various meanings. All positive deeds are just, but justice is also a feature of only some of man's deeds. Janina MAKOTA, "O sprawiedliwości [On Justice]," Kwartalnik Filozoficzny 26 (1998), vol. 2: 208-210. Jean-Paul Roux explained the fundamental character of the relationship between the sacred and justice in a simple way, quoting the Sasanid Book of the Crown in the Introduction to his work on myths and symbols of royal authority: "God in his justice created kings, so that this justice was realized, and injustice was abolished." Quoted after: Jean-Paul Roux, Król. Mity i symbole [The King: Myths and Symbols; French orig. Le roi, mythes et symboles], trans. Katarzyna Marczewska (Warszawa: Oficyna Wydawnicza Volumen, 1998), 5.

${ }^{9}$ HÖFFE, Sprawiedliwość polityczna, 19.

${ }^{10}$ Rawls, Teoria sprawiedliwości, 23. Directly from the theory of the contract the idea of justice as impartiality is derived that is propagated by Rawls.
} 
is not part of the discussion of the theory of the authority's justice. This side of human existence in a community may be defined as personal justice. In the personal meaning, a just person (a just king) recognizes the obligations of the law because he is convinced of them, and not because he is afraid of the penalty. Institutional praxis is a form of relations in a state and thanks to this it assumes a political character, which has resulted in it becoming the subject of the discussion below as institutional justice. The institution of royal authority, hedged with laws and obligations, defines rather clearly what is permissible and what is forbidden. This definition results in penalties for violating and breaking these rules. In the end, the very institution may be just or unjust. However, the very essence of institutional justice in a monarchy has at least two dimensions. The first one refers to the fundamental structure and the rules of justice accepted in the state (the laws defining the system), and the second one to the interpretation of these rules by the king. With such an approach this second dimension assumes a half-imperial and half-personal character. It becomes obvious that recognizing the first dimension as unjust also determines the appraisal of the king's interpretation as unjust. $^{11}$

Three main dimensions of the authority's justice were determined in ancient Greek philosophical discourse. According to Plato, justice consists of the principle "may all get their due". ${ }^{12}$ This idea was the result of a compre-

\footnotetext{
${ }^{11}$ Attention is often drawn to the common root in the Polish words "sprawiedliwość" ("justice") and "prawo" ("law"). This tendency has its source in the Latin terms "justitia" and "jus". This idealistic combination assumes that the law was created in order to seek justice. See SADURSKI, "Teoria sprawiedliwości," 77-78. Justice was very often applied in the institutional context. It was connected with the courts and generally with jurisdiction. See KLESzCZ, "Co to znaczy 'sprawiedliwość'?”, 38.

${ }^{12}$ Platon, Państwo [Plato, Republic], trans. Władysław Witwicki (Warszawa: Wydawnictwo Naukowe PWN, 1990), 35. According to its later title, Plato's Republic is a treatise On justice. Furthermore, in Aristotle's works a similar idea of justice appears; it consists of giving "to each his own". ARYSTOTELES, Etyka Nikomachejska [Aristotle, Nicomachean Ethics], trans. Daniela Gromska, in IDEM, Dzieta wszystkie [Collected Works], vol. V (Warszawa: Wydawnictwo Naukowe PWN, 1996), 170-172. However, this is a marginal statement in the Stagirite's work. According to Aristotle, justice, in a broader sense, is obeying the binding law - this justice is a general and complete virtue, because it contains all other virtues. ARYSTOTELES, Polityka. Z dodatkiem pseudo-arystotelesowskiej Ekonomiki [Aristotle, Politics. With pseudo-Aristotelian Economics added], trans. Ludwik Piotrowicz (Warszawa: PWN, 1964), 104-106, 229-230; ARYSTOTELES, Etyka Nikomachejska, 168-169, 171. Władysław Biegański distinguished in Aristotle’s works justice in a broader sense and in a stricter one. Justice in the broader sense would mean all morals and might be defined as "conscientiousness", and the term "justice" would refer to the stricter one. Władysław BIEGAŃSKI, Etyka ogólna [General Ethics] (Warszawa: Gebethner i Wolff, 1918), 334. Cf. Paul LAfargue, "Badania nad pochodzeniem pojęcia sprawiedliwości
} 
hensive analysis of both personal justice and institutional justice. Plato did not leave the decision about what is somebody's due to the ruler's decision. He pointed out that those who rendered services to the state - "to the men who went farther on the way of virtue"- deserve more. ${ }^{13}$ For Plato, justice was the "fair" distribution of wealth, status and power. "Fair" distribution meant distribution constituting the right order of things for society and for an individual's soul. And from this point there is only one step to what, in Plato's theory of authority, was the most important - justice was rewarding that which was in conformity with the natural order of things. Hence, it was not derivative of an individual's will. In the Platonic dialog the idea of justice as the will of an individual was represented by Socrates' adversary, Thrasymachus. He argued that the strength and authority of the ruler is the measure of justice, and ultimately it is his own liking. For Thrasymachus, pure strength in the service of the ruler's particular interests is the measure of power. Ultimately, justice is the benefit of the stronger one. Thrasymachus represents the amorality that will appear again in Machiavelli's thought. In this interpretation, the polis becomes a syndicate of the strong who, with a clear conscience, oppress and use the weak. And finally, between the justice introduced by the will of the ruler and the justice issuing from the natural order there is the justice of the contract (in terms of modern social contract) whose measures are laws (in Plato's Republic this idea was represented by Glaucon). In this third order what is legal is just. ${ }^{14}$ But this third conception was picked up (to a certain degree) by Hobbes who undermines the existence of a universal order, and defines man as a creature being directed solely by his own selfish interest. ${ }^{15}$ The binding category for this "third" theory of jus-

i pojęciem dobra [Research on the origin of ideas of justice and good; French orig. Le Déterminisme économique de Karl Marx. Recherche sur l'origine et l'évolution des idées de justice, du bien, de l'âme et de Dieu]," in IDEM, Pisma wybrane [Selected works], vol. 1 (Warszawa: Książka i Wiedza, 1981), 83-120. Aristotle called good forms of rule "just", meaning monarchy, aristocracy and constitutional government. Similar ideas are hard to find in Plato's works. However, in Aristotle, like in Plato, justice had a superior function over other virtues, like the foundation of the state.

${ }^{13}$ Platon, Prawa [Plato, Laws], trans. Maria Maykowska (Warszawa: PWN, 1960), 223. It seems that of the few who interpreted justice as recognizing special virtues and services, only Plato promoted the primacy of perfection, in which justice assumed the features of inequality.

${ }^{14}$ Platon, Państwo, 85.

${ }^{15}$ Thomas HoBbes, Lewiatan [Leviathan], trans. Czesław Znamierowski (Warszawa: PWN, 1954), 111-112. The interpretation of Hobbes' theory of justice is not unambiguous as the above short description may suggest. If justice in a universal meaning has a role in establishing a sovereign, then, after establishing him, only the sovereign's will counts. See HöFFE, Sprawiedliwość polityczna, 126. 
tice as mutuality is honoring the concluded contract. In this order, violating the contract is unjust, and justice becomes the fulfilling of obligations. Plato opened a discursive dispute concentrating on the dilemma whether one has to strive for just authority or for freedom from authority. He finds the former in a community with wise authority (knowledge) and moral efficiency (moderation, courage, personal justice). With the idealism characteristic of his era, he assumed that these values should not define all, but the ruling ones only. As a result, the rule of the philosopher (philosophers) only authorizes a just authority, and not any other.

The universal, classical idea of justice turned out to be exceptionally long-lasting. In the modern period, it was adapted to numerous conceptions of monarchist authority. On the principle of the paradox, Machiavelli supported the ruler's faithlessness with this theory, writing: "If men were entirely good this principle would not hold, but because they are bad, and will not keep faith with you [the Prince], you too are not bound to observe it with them". ${ }^{16}$ The ruler gives his subjects what is their due - so he is just. A negative diagnosis of the community of "the faithless" determines the way justice is realized.

The issue of a just authority was one of the main subjects not only in the theory of authority, but in philosophy as broadly understood. In the reflection developed within West-European civilization, a few axioms were formulated on the idea of the justice of authority. Significant findings were introduced into Western political reflection by St Thomas Aquinas, who certainly did so on the basis of ancient thought. He considered a uniform, that is monarchist, government, and not an aristocratic one, the more so because democracy is not uniform, the more just. ${ }^{17}$ In this way he consolidated the faith in the justice of the authority of the individual. The ideas defining the relationship between the law and justice were fundamental in the European theory of authority. It was a relationship that was emphasized by the theoreticians of authority with Jean Bodin at the head. It was exactly this French theoretician who recognized this government as a just one that is subordinate to God's law and the cardinal laws (in the sense of natural laws) only. Let us remember that, for Bodin, a monarchy was the best system we can acquire, in his interpretation, and thus the ideal of a just ruler. A ruler for whom it is easy to determine which laws he is to obey. But at the same time he may not be con-

\footnotetext{
${ }^{16}$ Nicolò MAChiaVelli, Książę [The Prince], trans. Czesław Nanke and Krzysztof Żaboklicki (Warszawa: Państwowy Instytut Wydawniczy, 1984), 807.

${ }^{17}$ Św. Tomasz z AKwinu [St Thomas Aquinas], O władzy [On Kingship], trans. Jacek Salij, in IDEM, Dzieła wybrane [Selected works] (Kęty: Antyk, 1999), 233.
} 
trolled in the realization of these laws. ${ }^{18}$ In the idea of authority defined in this way, the law becomes the supreme manifestation of sovereignty and, at the same time, it is the sovereign's order. As a result of generating these kinds of new theories the Platonic ideal of three orders of justice began to be "blurred". With time, intermediate ideas between the idea of justice coming from the nature, the idea of justice coming from the will of the ruler and the legal order of the contract started to appear.

The Old Polish political thought defined the idea of royal justice fairly precisely. As Urszula Augustyniak argues, in Poland the beginnings of the modern idea were built by Andrzej Frycz Modrzewski, and he was followed by other theoreticians of the $16^{\text {th }}$ and political writers of the $17^{\text {th }}$ centuries. In this way they shaped the notions that the broader circles of noblemen had. ${ }^{19}$ Among the fundamental features of the ideal king, apart from justice, Modrzewski mentioned moderation, generosity and valor. But he added that "the best of virtues is justice". ${ }^{20}$ According to Modrzewski's simple definition justice was the most important of the monarch's virtues. The monarch realized this virtue when he served the state by putting his subjects' interest over

\footnotetext{
${ }^{18}$ Jean Bodin, Sześć ksiag o Rzeczypospolitej [The Six Books on the Republic], trans. Zygmunt Izdebski (Warszawa: PWN, 1958), 264-266. It was exactly Bodin who defined anew in the European political theory the term of sovereign authority. Such authority may do anything except breaking God's law and natural laws. Its essence (and so the essence of sovereignty) is reduced to the power of creating and annulling the law, with the exception of the abovementioned God's law and natural laws. Hence, the sovereign's unlimited legislative power concerns state law. In the earlier, "medieval", political theory the authority's main aim was to settle disputes. This is what the sovereignty of the authority was based on, the authority whose essence was adjudicating. Lech DuBEL, Historia doktryn politycznych i prawnych do schyłku XX wieku [History of Political And Legislative Doctrines Until the Close of the $20^{\text {th }}$ Century], Warszawa: Wydawnictwo Naukowe PWN, 2005), 153.

${ }^{19}$ Urszula AUGUSTYNIAK, Wazowie i , królowie rodacy”. Studium władzy królewskiej w Rzeczypospolitej XVII wieku [The House of Vasa and the "Compatriot Kings": A Study of Royal Authority in the Republic of Poland in the $17^{\text {th }}$ Century] (Warszawa: Semper, 1999), 55.

${ }^{20}$ Andrzej Frycz ModrzewSKI, O poprawie Rzeczypospolitej [On the Improvement of the Commonwealth], in Filozofia i myśl społeczna XVI wieku [Philosophy and Social Thought of the $16^{\text {th }}$ Century], ed. Lech Szczucki (Warszawa: PWN, 1978), 254. Cf. Stanisław PIwKo, Frycza Modrzewskiego program reformy państwa i Kościoła [Frycz Modrzewski's Program of Reform of the State and the Church] (Warszawa: Akademia Teologii Katolickiej, 1979), 58; Waldemar VoISÉ, Frycza Modrzewskiego nauka o państwie i prawie [Frycz Modrzewski's Teaching on the State and Law] (Warszawa: Książka i Wiedza, 1956), 138. Emphasizing justice after Modrzewski, as the ideal king's leading feature, was fairly accurately repeated by Jakub Przyłuski. See Jakub PrZYŁuski, Prawa, czyli statuty i przywileje Królestwa Polskiego [Laws or Statutes and Privileges in the Kingdom of Poland], in 700 lat myśli polskiej. Filozofia i myśl spoleczna XVI wieku [700 Years of the Polish Thouhgt: Philosophy and Social Thouhgt of the $16^{\text {th }}$ Century], ed. Lech Szczucki (Warszawa: PWN, 1978), 207.
} 
his own benefit. It should be remembered here that Modrzewski, like many of his contemporary Polish thinkers, gave his justification a theologicalmoral character. ${ }^{21}$ Religion was the source of civic attitude for him. Thus, the separation of politics and religion (the political virtue opposing the religious), known, for instance, from borrowings practised in Italian universities, did not catch on in Poland.

Justice was often the ruler's leading virtue, but it was always mentioned among many other features. In the $16^{\text {th }}$ century a special model of the presentation of the ideal of the king dominated. It emphasized the features of the king as a man, and only to a lesser degree as a politician. This model again became attractive in the $18^{\text {th }}$ century. Restoring this ideal had a distinctive specificity. I feel it was more a proof of referring to Renaissance humanism than a real ideal of the ruler. The ideal king of the period when Renaissance humanism dominated in European culture was to be marked by a whole set of personal features: humanitarianism, charity, modesty, moderation, wisdom, but also piety. Along with the reference to piety that was so commonly mentioned in royal mirrors of the $16^{\text {th }}$ century, a dilemma concerning the outlook also arose.

On the legalist ground the definition of justice was equally simple. The king in the Republic of Poland was obliged to act according to legal norms. Legalism defined in this way became the foundation of the Old Polish system of political values. ${ }^{22}$

Many philosophers of politics and theoreticians of authority have pointed to the key role of justice in the discussion of the theory of politics and the idea of the state. ${ }^{23}$ This desideratum is equally clear in Plato's works and in works by modern authors. For these thinkers Plato's idea of justice was and still is the central theme.

The principle saying that justice is the most important value of authority was referred to by theoreticians of politics in hundreds of ways. However, such an approach, as Teresa Kostkiewiczowa noted, was rarely followed by

\footnotetext{
${ }^{21}$ On the biblical inspirations of Modrzewski's thought see PIwKO, Frycza Modrzewskiego program, 58-59; VoISÉ, Frycza Modrzewskiego nauka, 62.

${ }^{22}$ Edward OpALIŃSKI, Kultura polityczna szlachty polskiej w latach 1587-1652. System parlamentarny a spoleczeństwo obywatelskie [The Political Culture of Polish Noblemen in the Years 1587-1652. The Parliamentary System and Civic Society] (Warszawa: Wydawnictwo Sejmowe, 1995), 96.

${ }^{23}$ HÖFfe, Sprawiedliwość społeczna, 7; Zbigniew StAwrowski, "O dwóch miarach sprawiedliwości [On Two Measures of Justice]," Civitas 2000, No. 4: 33-47; Justyna MikLASZEwSKA, "Sprawiedliwość libertariańska [Libertarian Justice]," Civitas 2000, No. 4: 99.
} 
at least an attempt to explain the idea of the justice of authority ${ }^{24}$ Examples of such rhetoric are countless. Jan Marczewski enigmatically noted that "there is no proper act for a monarch greater than the virtue of justice and keeping to it seriously". ${ }^{25}$ A lot more examples of similar statements may be cited. The subject of the superiority of justice in the process of exercising authority was discussed by Grzegorz Piramowicz, ${ }^{26}$ Wincenty Skrzetuski ${ }^{27}$; justice as the true and ultimate aim of a ruler was indicated by Józef Wybicki $^{28}$ and Stanisław Staszic. The latter, in Przestrogi dla Polski [Warnings for Poland], stated that "justice is the first and sacred obligation of a king". ${ }^{29}$ However, he did not define here the term "justice", as he had done earlier in his Uwagi nad zyciem Jana Zamoyskiego [Remarks on the Life of Jan Zamoyski].

\footnotetext{
${ }^{24}$ Teresa KostKiewiczowA, "Publicystyka Franciszka Salezego Jezierskiego z lat 1788-1791. Z zagadnień literackiej perswazji [Franciszek Salezy Jezierski’s Writings of 1788-1791. From the Issues of the Literary Persuasion]," in Sejm Czteroletni i jego tradycje (The Four-Year Sejm and Its Traditions), ed. Jerzy Kowecki (Warszawa: Wydawnictwo Naukowe PWN, 1991), 127. Perhaps expecting a profound reflection on the idea of justice is naïve. Maybe the theory of justice has, as Vilhelm Lundstedt argued, only an ideological dimension and as such is a "pure fabrication". But this theory also leads us to the conclusion that justice has no sense, but that it lacks this sense only in the theory of law. This does not change the fact that Lundstedt connected justice with ideology and defined it as a pure fabrication. Vilhelm LunDSTEDT, "Law and Justice: A Criticism of the Method of Justice," in Interpretation of Modern Legal Philosophy, edited by Paul Sayre (New York: Oxford University Press, 1947), 450.

${ }^{25}$ Jan MARCZEwSKI, Dzień uroczysty S. Stanisławowi Biskupowi Męczennikowi poświęcony oraz Imieninami rocznemu Najjaśniejszego Króla Jmci Polskiego Stanisława Augusta zaszczycony, kazaniem w kościele Farnym Bydgoskiem w przytomności J. O. Trybunatu Koronnego [...] przez podanie[...] do druku ogloszony od X. [...] z Towarzystwa Jezusowego wzwyż wyrażonego Kościoła Kaznodzieje (The Solemn Day Devoted to St Stanisław Bishop the Martyr and Honored by His Majesty the King of Poland's Name Day, With a Sermon Said by a Preacher of the Said Church in the Bydgoszcz Parish Church in the Presence of Their Lordships the Crown Tribunal [...] Pubished by Printing by Fr. [...] of the Society of Jesus, [place of publication not given] 1768 , k. C 2 v.

${ }^{26}$ Grzegorz PIRAMOwicz, Przestrogi dla czytajacych pisma historyczne-polityczne, jako to pamiętniki, dzienniki, wojaże, geografie i tym podobne [Warnings for Readers of HistoricalPolitical Writings, Like Memoirs, Journals, Voyages, Geographies and the Like] (Warszawa: W Drukarni J. K. Mci i Rzeczypospolitey u XX. Scholarum Piarum, 1787), 99.

${ }^{27}$ Wincenty SKRZETUSKI, Prawo polityczne narodu polskiego [|Political Law of the Polish Nation], vol. I (Warszawa: W drukarni J. K. Mci i Rzeczypospolitey u XX. Scholarum Piarum, $1782), 118$.

${ }^{28}$ Józef WyBICKI, Myśli polityczne o wolności cywilnej [Political Thoughts About the Civil Liberty], ed. Emanuel Rostworowski (Wrocław: Ossolineum, 1984), 76; IDEM, Listy patriotyczne [Patriotic Letters] (Wrocław: Ossolineum, 1955), 37.

${ }^{29}$ Stanisław Staszic, Przestrogi dla Polski [Warnings for Poland] (Wrocław: Ossolineum, 2003), 203
} 
These statements only prove that justice was an absolutely permanent value. In the case of these extremely general interpretations, justice is the most important aim of the authority of an individual. For my argument it is more important that it can be such an important aim. It is exactly Wybicki, mentioned above, who more often than his contemporaries referred to the deeper layers of the axiology of value. Maybe it was a consequence of his monarchist sympathies. In his interpretation, justice is: "to know what to forgive and to punish in people; when giving, to see justice without that severity that makes it too terrible". ${ }^{30}$ Wybicki "dreamt" of justice that would not be too severe (by nature). He realized that the idea of justice may require sacrificing one's happiness and cannot be fully combined with political freedom. Wybicki seemed to say that freedom is less important than honesty, and those who are not just of their own free will have to be forced to be just. However, in the case of such coercion, severity (which he tried to avoid) is indispensable. It seems that Józef de Puget-Puszet realized this fact better when he noted: "severity is the only means for stopping delinquency". ${ }^{31}$

When, in Porzadek fizyczno-moralny [Physical-Moral Order], published in 1810, Hugo Kołłataj ponders the aims of authority, he recognizes justice as the leading value, like his predecessors did, with the difference that Kołłataj does not see any role for the king in achieving this aim of authority. ${ }^{32}$ In the new interpretation, a new society was to be built by collegial authority, and not by the authority of an individual.

At the opposite end of the $18^{\text {th }}$-century theory of authority there are ideas propagating giving the king all of the authority over jurisdiction. Such a postulate was forced by Ignacy Łobarzewski in Zaszczyt wolności polskiej [The Honor of Polish Liberty]. He suggested that justice should be the king's first prerogative. $^{33}$

This expansion of the monarch's competences was to happen with the throne maintaining the right to nominate candidates for offices and to reward

\footnotetext{
${ }^{30}$ WYBICKI, Listy patriotyczne, 32. The same way of perceiving justice may be found in David Hume's works. This may show that Wybicki borrowed some ideas. See Sharon R. KRAUSE, "Hume and the (False) Lustre of Justice," Political Theory 32 (2004), No. 5: 647.

${ }^{31}$ Józef DE PUGeT-Puszet, O uszczęśliwieniu narodu [On Making the Nation Happy], vol. II (Warszawa, 1789), 34.

${ }^{32}$ Hugo KoŁŁĄTAJ, Porzqdek fizyczno-moralny [Physical-Moral Order], ed. Kazimierz Opalek (Warszawa: PWN, 1955), 114-115.

${ }^{33}$ Ignacy ŁOBARZEWSKI, Zaszczyt wolności polskiej angielskiej wyrównujacy, z uwagami do tego stosownymi i opisaniem rzqdu angielskiego [The Honor of Polish Liberty Equal to English, With Adequate Remarks and With a Description of the English Government] (Warszawa, 1789), 35.
} 
the subjects. ${ }^{34}$ The ideal of the king as the defender of law and justice is also clear in Staszic's works, when in Uwagi nad życiem Jana Zamoyskiego he stated: "the king will be the guardian of executing all laws". ${ }^{35}$ There were a lot of models for such ideas, apart from the English political system. Such an ideal was given to Poles, which may be surprising, by Jean Jacques Rousseau himself, who thought that the king's aim is maintaining a justice that was defined as care for the flawlessness of all tribunals. The king, "a born judge of his people", in the interpretation of the philosopher of Geneva, was to have the supreme power of jurisdiction. ${ }^{36}$ An ideal that is close to this may be found in the otherwise monarchist utopia ascribed to Stanisław Leszczyński. After all, it was the monarch who directly supervised dispensing justice in an ex-king's ideal state: "the monarch pays judges, and at the same time enlightens them, his wisdom and vigilance rewards or punishes, his dignity limits their authority so that they do not abuse it". ${ }^{37}$

In both a characteristic and representative way the anonymous author of Uwagi nad pochwata wieku osiemnastego [Remarks on the Praise of the

\footnotetext{
${ }^{34}$ Ibid., p. 36.

${ }^{35}$ Stanisław STASZIC, Uwagi nad życiem Jana Zamoyskiego [Remarks on the Life of Jan Zamoyski], ed. Stefan Czarnowski (Wrocław: Ossolineum, 2005), 215. In his later Przestrogi dla Polski he contradicted the above remark limiting the king's influence on jurisdiction and justice in the extreme. He did so arguing that such influence would limit the subjects' equality, liberty and right to property. "Only universal will [Staszic wrote] may establish judicative magistratures, grant them authority and describe the ways of investigating and hearing cases to decide if the proofs presented by the complainant are true. And the penalty will be imposed by the law itself. There is no equality, liberty or property, human rights are violated, where one citizen has the authority of appointing judges for his co-citizens". Przestrogi dla Polski, 24. Staszic even considered the king appointing judges to be unacceptable. The idea of justice as the supervision over judges will often recur in Polish reflections on politics, see Michał KARPOwICZ, O uszanowaniu $i$ postuszeństwie królom [On Respect and Obedience to Kings] (Grodno, 1775), 201.

${ }^{36}$ Jean Jacques Rousseau, Considérations sur le Gouvernement de Pologne, in: Oeuvres complètes, vol. VII (Paris: Didot, 1857), 993. Associating the person of the king with exercising jurisdiction was exceptionally long-lasting. Even depriving the person of the English king of the right to dispense justice by the Declaration of the House of Lords and the House of Commons of $27^{\text {th }}$ May 1642 did not mean giving up the traditional titulature. The text of the Declaration itself said that justice dispensed in the country would still be the justice of the king, albeit it would not be dispensed by his person by the use of his will, but by his courts of justice. Ernst H. KANTORowicz, Dwa ciała króla. Studium ze średniowiecznej teologii politycznej [The King's Two Bodies: A Study in the Medieval Political Theology], trans. Maciej Michalski and Adam Krawiec (Warszawa: Wydawnictwo Naukowe PWN, 2007), 17.

${ }^{37}$ Stanisław LESZCZYŃSKI, "Rozmowa Europejczyka z wyspiarzem z królestwa Dumocala [A Conversation of a European with an Islander from Dumocal's Kingdom]," in IDEM, Glos wolny wolność ubezpieczajacy [A Free Voice Securing Liberty] (Lublin: Krajowa Agencja Wydawnicza, 1987), 57.
} 
Eighteenth Century] understood justice as the aim of royal authority. For him, an ideal king's justice simply meant obeying political laws. ${ }^{38}$ This legalist idea of justice, well understood by the broad groups of the "political nation" (the noblemen), was probably its most universal definition. Maybe by heading towards the expectations of broad groups of noblemen justice can be reduced to just the openness of the procedure of its dispensing. In this case, the dispute over justice would lose its theoretical character; it would assume a formal one. It is also hard to expect Polish noblemen to appraise the justice system as being unjust, for only the imperial-personal interpretation of laws made by the king could be appraised by the "political nation". The interpretation in which he would be guided by his interests only and not by legality raised universal opposition as an instance of injustice. This proves that the Old-Polish idea of legalism was indisputable.

The dispute that is always present in the theory of authority over the question whether, in building political ideas, one should stick to the old proven solutions or to reach for new and inventive ideas became especially dramatic, intensive and expressive in the second half of the $18^{\text {th }}$ century. Its character is perfectly well reflected by the motto propagated by Hieronim Stroynowski, that overstepping the rules of natural justice is an indicator of harm being done to those being ruled. ${ }^{39}$ This inventive motto of natural justice became a new paradigm for the theory. Stroynowski defined it, I feel, most accurately; however, it was not he who introduced the idea to Poland. The motto appeared among the initiators of a codification of Polish law by the Sejm as early as $1776 .{ }^{40}$ The idea was based on the theory of natural law and directly referred to the catalogue of natural laws, with the inviolability of property, the duty to indemnify damages and the honoring of contracts, as well as with the need to impose penalties for crimes and offences. After the Kodeks Zamoyskiego (Zamoyski's Code) based on the principle of natural justice had been rejected Remigiusz Ładowski noted that a ruler is just if he

\footnotetext{
${ }^{38}$ Uwagi nad pochwata wieku osiemnastego [Remarks on the Praise of the Eighteenth Century], [place of publication not given] [1785], p. 8. Antoni Popławski is usually considered to be the author of the text.

${ }^{39}$ Hieronim STROYNOWSKI, Nauka prawa przyrodzonego, politycznego, ekonomiki politycznej i prawa narodów [The Science of Natural, Political Law, Political Economy and the Law of the Nations] (Wilno: W drukarni królewskiej przy Akademii, 1785), 137-138.

${ }^{40}$ See Ewa BorkowskA-BAgieńSKA, ,Zbiór praw sqdowych” Andrzeja Zamoyskiego [Andrzej Zamoyski's “A Collection of Court Laws”] (Poznań: Wydawnictwo Naukowe Uniwersytetu im. Adama Mickiewicza, 1986), 60; Kazimierz OPAŁEK, „Wstęp [Introduction]”, in WyBICKI, Listy patriotyczne, XXXIV.
} 
"agrees with natural and God's laws". ${ }^{41}$ Thus, the "fashionable" formula took root in the thought about the justice of authority.

The theoreticians of authority of the second half of the $18^{\text {th }}$ century must have often asked the question whether people are unequal in their very essence? Maybe they did so more often than thinkers in other eras. If so, if people are unequal, then justice has to recognize services and achievements and it will be easier for us to accept tradition as a political aim, for tradition always has considerable inequalities in it. Such an attitude was in accordance with the Platonic idea of natural justice. And if people are equal, it means that they have the right to individualism. Each of them may live in harmony with his choice. The modern ideal of equality gives us a basis for affirming egalitarian justice and community, since equality abolishes such differences as authority and social status, differences that divide people. In modern times, only utopians wrote about such equality; they reduced authority to a "natural" minimum. If the above question is answered positively (people are unequal in their very essence), it is easy to arrive at the thesis that institutional justice may always (on principle) be unjust, because the distribution of natural talents is unjust. And this injustice may be transferred to the system of distribution and redistribution. Thus, maybe justice should be reduced to rewarding and punishing the subjects "appropriately". Rewarding adequately the merits of those ruled, as Plato formulated it. Although certainly this "appropriateness" of the royal decision is an exceptionally ambiguous category here, the ideas of justice to a varying degree may take into consideration the idea of the common good and equality.

The symbol of the state is the sword, which is a sign of the exclusiveness of ruling and the condition for realizing the monopoly of authority, and more precisely the monopoly for administering law. The question whether a ruler uses the sword sovereignly, or in the service of justice in the name of giving up freedom, is an individual problem. Most Polish theoreticians of authority in the second half of the $18^{\text {th }}$ century consistently knocked the sword of authority out of the king's hand. In this way, the Old Polish legalism was transferred to the thought about the state in the epoch of Enlightenment as well. The sword is also a symbol of justice that takes the place of the sovereign as an emanation of independence from authority. The sword of justice seemed to be the only tool that Polish monarchist theoreticians of authority were willing to give to the monarch. But even in the monarchist circles the range

\footnotetext{
${ }^{41}$ Remigiusz ŁADOwSKI, Krótkie zebranie trzech praw poczatkowych [A Short Summary of the Three Basic Laws] (Lwów, 1780), 91.
} 
of the monarch's use of this dangerous tool was disputable. Certainly, promoting the idea of judging by personal authority would be propagating brute strength. The essence of such authority can be reduced to having sufficient strength to deny the administration of justice or to make justice dependent on one's own will. Hence, the monopoly on exertion is not measured by the strength of the administration of justice only, but also by the possibility not to administer it. It seems that ideas of the justice of the will could not come into being in Polish theory. On the other hand, the issue is ambiguous, as the sword that is held by justice is just a simple symbol of strength, and as such it is not bound up with justice itself. As an instrument of strength it may both serve justice and endanger it. The sword will become the instrument of justice when it loses its double-edged character and, as a rule, will be bound with justice only. Bringing about such a state has become the idea of modern justice, and moreover, it is an idea that was very close to the Polish theoreticians of authority in the second half of the $18^{\text {th }}$ century, theoreticians whoI think - did not even admit that the thought of administering justice on the basis of the free will of individual authority was possible.

\section{BIBLIOGRAPHY}

Arystoteles, Polityka. Z dodatkiem pseudo-arystotelesowskiej Ekonomiki [Aristotle, Politics. With pseudo-Aristotelian Economics added]. Translated by Ludwik Piotrowicz. Warszawa: PWN, 1964.

ARYstoteles. Etyka Nikomachejska [Aristotle, Nicomachean Ethics]. Translated by Daniela Gromska. In IDEM, Dzieła wszystkie [Collected Works]. Vol. V. Warszawa: Wydawnictwo Naukowe PWN, 1996.

AugustyniaK, Urszula. Wazowie i „królowie rodacy”. Studium władzy królewskiej w Rzeczypospolitej XVII wieku [The Vasas and the "Compatriot Kings": A Study of Royal Authority in the Republic of Poland in the $17^{\text {th }}$ Century]. Warszawa: Semper, 1999.

BIEGAŃSKI, Władysław. Etyka ogólna [General Ethics]. Warszawa: Gebethner i Wolff, 1918.

Bodin, Jean. Sześć ksiag o Rzeczypospolitej [The Six Books on the Republic]. Translated by Zygmunt Izdebski. Warszawa: PWN, 1958.

HöFFE, Otfried. Sprawiedliwość polityczna. Podstawy krytycznej filozofii prawa i państwa [Political Justice. The Foundations of Critical Philosophy of the Law and the State]. Translated by Jarosław Merecki. Kraków: Znak, 1999.

Kantorowicz, Ernst H. Dwa ciała króla. Studium ze średniowiecznej teologii politycznej [The King's Two Bodies: A Study in the Medieval Political Theology]. Translated by Maciej Michalski and Adam Krawiec. Warszawa: Wydawnictwo Naukowe PWN, 2007.

KLeszcz, Ryszard. "Co to znaczy 'sprawiedliwość'? (What Does 'Justice' Mean?).” Filozofia Nauki 1999, No. 1/2: 31-41.

KostKiewiczowa, Teresa. "Publicystyka Franciszka Salezego Jezierskiego z lat 1788-1791. Z 
zagadnień literackiej perswazji [Franciszek Salezy Jezierski's Writings of 1788-1791. From the Issues of the Literary Persuasion]." In Sejm Czteroletni i jego tradycje (The Four-Year Sejm and Its Traditions), edited by Jerzy Kowecki. Warszawa: Wydawnictwo Naukowe PWN, 1991.

Krause, Sharon R. "Hume and the (False) Lustre of Justice." Political Theory 32 (2004), No. 5: 628-655.

LAfargue, Paul. "Badania nad pochodzeniem pojęcia sprawiedliwości i pojęciem dobra" [Research on the origin of ideas of justice and good; orig. fr. "Le Déterminisme économique de Karl Marx. Recherche sur l'origine et l'évolution des idées de justice, du bien, de l'âme et de Dieu']. In IDEM. Pisma wybrane [Selected works]. Vol. I, 83-120. Warszawa: Książka i Wiedza, 1981.

LUNDSTEDT, Vilhelm. "Law and Justice: A Criticism of the Method of Justice." In Interpretation of Modern Legal Philosophy, edited by Paul Sayre, 415-452. New York: Oxford University Press, 1947.

Machiavelli, Nicolò. Ksiażę [The Prince]. Translated by Czesław Nanke and Krzysztof Żaboklicki. Warszawa: Państwowy Instytut Wydawniczy, 1984.

MaкотA, Janina. "O sprawiedliwości [On Justice]." Kwartalnik Filozoficzny 26 (1998), vol. 2: $207-222$

MiklaszewsKa, Justyna. "Sprawiedliwość libertariańska [Libertarian Justice]," Civitas 2000, No. 4: $99-118$

ModRzewSKI, Andrzej Frycz. O poprawie Rzeczypospolitej [On the Improvement of the Commonwealth]. In Filozofia i myśl społeczna XVI wieku [Philosophy and Social Thought of the $16^{\text {th }}$ Century], edited by Lech Szczucki. Warszawa: PWN, 1978.

OPALIŃSKI, Edward. Kultura polityczna szlachty polskiej w latach 1587-1652. System parlamentarny a spoleczeństwo obywatelskie [Political Culture of Polish Noblemen in the Years 1587-1652: The Parliamentary System and the Civic Society]. Warszawa: Wydawnictwo Sejmowe, 1995.

Pawelec, Andrzej. "Ontologia sprawiedliwości [Ontology of Justice].” Civitas 2000, No. 4: 133-143.

PIwKo, Stanisław. Frycza Modrzewskiego program reformy państwa i Kościoła [Frycz Modrzewski's Program of Reform of the State and the Church]. Warszawa: Akademia Teologii Katolickiej, 1979.

Platon, Państwo [Plato, Republic]. Translated by Władysław Witwicki. Warszawa: Wydawnictwo Naukowe PWN, 1990.

Platon, Prawa [Plato, Laws]. Translated by Maria Maykowska. Warszawa: PWN, 1960.

PrzyŁuski, Jakub. Prawa, czyli statuty i przywileje Królestwa Polskiego [Laws or Statutes and Privileges in the Kingdom of Poland]. In 700 lat myśli polskiej. Filozofia $i$ myśl spoleczna XVI wieku [700 Years of the Polish Thouhgt: Philosophy and Social Thouhgt of the $16^{\text {th }}$ Century], edited by Lech Szczucki. Warszawa: PWN, 1978.

RAwLS, John. Teoria sprawiedliwości [Theory of Justice]. Translated by Maciej Panufnik, Jarosław Pasek, and Adam Romaniuk. Warszawa: Wydawnictwo Naukowe PWN, 1994.

Roux, Jean-Paul. Król. Mity i symbole [The King: Myths and Symbols; French orig. Le roi, mythes et symboles]. Translated by Katarzyna Marczewska. Warszawa: Oficyna Wydawnicza Volumen, 1998.

SAdurski, Wojciech. Teoria sprawiedliwości. Podstawowe zagadnienia [The Theory of Justice. Fundamental Issues]. Warszawa: Państwowe Wydawnictwo Naukowe, 1988.

SiemianowsKi, Antoni. "Sprawiedliwość [Justice]." Logos i Ethos 1993, No. 2: 7-31. 
STASZIC, Stanisław. Uwagi nad życiem Jana Zamoyskiego [Remarks on the Life of Jan Zamoyski], edited by Stefan Czarnowski. Wrocław: Ossolineum, 2005.

Stawrowski, Zbigniew. "O dwóch miarach sprawiedliwości [On Two Measures of Justice]." Civitas 2000, No. 4: 33-47.

Św. Tomasz z Akwinu [St Thomas Aquinas]. O władzy [On Kingship]. Translated by Jacek Salij. In IDEM. Dzieła wybrane [Selected works]. Kęty: Antyk, 1999.

VoIsé, Waldemar. Frycza Modrzewskiego nauka o państwie i prawie [Frycz Modrzewski's Teaching on the State and Law]. Warszawa: Książka i Wiedza, 1956.

WEAVER, Richard M. Idee maja konsekwencje [Ideas Have Consequences]. Translated by Barbara Bibula. Kraków: Profesjonalna Szkoła Biznesu, 1996.

\section{JUSTICE AS THE AIM OF THE MONARCH'S RULE: THE EVOLUTION OF THE IDEA FROM PLATO TO THE CLOSE OF THE ENLIGHTENMENT}

\section{S u m m a r y}

The idea of the justice of the authority in the general meaning remains a central topic in Polish political theory. This has resulted in the frequent tackling of this problem, but it has not been reflected in the complexity of the theory. It is even difficult to talk about a theory in the case of the considerations analyzed. They were mostly very superficial mentions of the monarch's justice, permeated with old-Polish legalism, a legalism reduced to the rule: the king is obliged to observe legal norms and to give priority to the good of those ruled over his own interests. This model determined the deliberations about justice. Most theoreticians could not see the possibility of strengthening the king's influence on dispensing justice in the country, although there were exceptions to this view and not only among monarchists. Owing to this model in Polish political thought, after the fall of the First Republic of Poland it was easier to accept the idea of justice dispensed by broad bodies representing the community. The model was not even overturned by the instrumental transfer of the idea of natural justice to Poland. It was also not overturned by the doubts expressed by Wybicki about the possibilities of linking justice to the subjects' happiness and political freedom.

Key words: idea of justice; authority; theory of authority; philosophy of politics.

Translated from Polish by Tadeusz Karlowicz

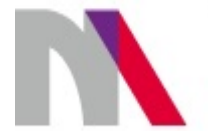

The preparation of the English version of Roczniki Humanistyczne and its publication in electronic databases was financed under contract no. 836/P-DUN/2018 from the resources of the Minister of Science and Higher Education for the popularization of science. 